\title{
L'art lul·liana com a teologia filosòfica
}

\author{
Josep BATALLA \\ Fundació Quer Alt
}

direccio@obradoredendum.cat

Resum: L'article defensa que l'Art lul-liana és un sistema de teologia filosòfica. Des d'aquesta perspectiva, l'article critica l'intent de reduir l'Art a una proposta purament epistemològica elaborada per Llull amb la finalitat de corregir els defectes inherents a la teoria aristotèlica de la ciència. Aquesta crítica obliga a posar de manifest la ideologia secular subjacent a la interpretació de l'Art lul-liana com una proposta epistemològica.

Paraules clau: teologia filosòfica, epistemologia, aristotelisme, secularisme.

Abstract: The article contends that Llull's Art is a system of philosophical theology. From this point of view, the article criticizes the attempt to reduce the Art to a purely epistemological proposal designed by Lull in order to correct the defects inherent in the Aristotelian theory of science. This critical remark compels to highlight the secular ideology underlying the interpretation of Llull's Art as an epistemological proposal.

Key words: philosophical theology, epistemology, aristotelism, secularism

Un personnage sçavant n'est pas sçavant par tout; mais le suffisant est par tout suffisant, et à ignorer mesme.

Montaigne, Essais, 3.2

I do not ask anyone to think in my terms if he prefers others. Let him clean better, if he can, the windows of his soul, that the variety and beauty of the prospect may spread more brightly before him.

George Santayana, Scepticism and Animal Faith, Preface 


\section{MENES DE LUL·LISME}

Com la dels clàssics, l'obra de Llull pot ésser objecte avui dia de múltiples lectures. Ho permet la pluralitat de valors en circulació. ${ }^{1}$ La manera de llegir Llull dependrà, doncs, de les opcions inicials que prenguem i dels pressupòsits que acceptem. Hi ha cap tema dominant entorn del qual calgui estructurar totes les idees de Llull? Hem de privilegiar cap dels diversos gèneres en què s'expressà Llull: reflexió filosòfica, apologètica religiosa, literatura d'idees? A quines obres cal donar prioritat? Creiem que la interpretació genètica de l'obra de Llull ha de prevaler sobre la sistematització del seu pensament? Quin valor atribuïm al pensament de Llull, al marge de la seva finalitat apologètica originària? Quina mena de validesa lògica concedim a l'Art?

Hi ha hagut i hi haurà moltes menes de lul-lisme perquè la pluralitat de lectures és inevitable. M'adhereixo al pluralisme proposat per Nicholas Rescher per a encaminar la recerca: cal partir d'un racionalisme que, si bé reconeix que es troba inevitablement limitat per les circumstàncies en què sorgeix i es desenvolupa (contextualistic rationalism), es nega a admetre el relativisme radical que aboca al nihilisme, com també es refusa a acceptar l'absolutisme dels qui creuen que poden assolir l'única veritat. ${ }^{2}$

La qüestió no és, doncs, de saber si hi pot haver diversos lul-lismes amb la corresponent disparitat de valoracions, ${ }^{3}$ sinó de decidir si tots els lul·lismes són igualment vàlids —atès que es fa molt difícil de sostenir que tot s'hi val. ${ }^{4}$ Les impostures intel-lectuals no són pas impossibles, especialment en ciències humanes. ${ }^{5}$ Sembla innegable que hi pot haver hipòtesis que es mostrin inversemblants, suposicions que calgui tenir per infundades, mètodes que siguin inadequats, argumentacions que es revelin incorrectes, i també recerques que resultin banals perquè demostren allò que tothom ja sap o perquè descobreixen quelcom que es mostra irrellevant.

Però, per damunt de tot, cal no perdre de vista que les interpretacions parteixen sempre de judicis previs. Creure que podem interpretar un autor - Llull,

${ }^{1}$ Frank Kermode, The Classic (Cambridge, Massachusetts: Harvard University Press, 1983) p. 139: «Secularization multiplies the world's structures of probability, as the sociologists of religion tell us, and this plurality of religious legitimations is internalized in consciousness as a plurality of possibilities between which one may choose».

${ }_{2}$ Nicholas Rescher, Pluralism. Against the Demand of Consens (Oxford: Clarendon, 2000), p. 4: «In the setting of issues regarding knowledge and inquiry it can, properly configured, lay the basis for a contextualistic rationalism intermediate between dogmatic absolutism on the one hand and relativistic relativism on the other.»

${ }^{3}$ Lluís Sala-Molins, El gegantisme de la raó lul-liana (Palma de Mallorca: Centre d'estudis teològics de Mallorca, 1989), p. 7: D'interpretacions de Llull «—diverses, harmòniques i complementàries entre si, o diametralment contràries o contradictòries- se n'han proposat des del primer lul-lisme fins avui arreu d'Europa. No vull dir que a can Llull sigui a can Seixanta on cadascú és fica on vol, remena com li sembla fins que en surt per on li agrada quan n'està tip.»

${ }^{4}$ La consigna de Paul K. Feyerabend, Against Method (Londres: Verso, 1993) p. 14: «The only principle that does not inhibit progress is: "anything goes"», és, evidentment, una atzagaiada parenètica.

5 Jean Bricmont i Alan Sokal, Impostures intel-lectuals (Barceloma: Empúries, 1999). 
en el nostre cas- sense cap mena de prejudici és una il-lusió d'allò més ingènua. ${ }^{6}$ Prèviament, tots donem per vàlid allò que configura la nostra visió del món $i$ de què no ens podem desfer. Tant si no ens fa res de reconèixer-ho com si ens molesta d'haver-ho de fer, ens trobem sempre immersos en un cercle hermenèutic, no sols mentalment, sinó sobretot realment: ${ }^{7}$ només cerquem allò que volem trobar i ho cerquem perquè esperem poder treure'n algun profit — sia per a afermar les nostres preferències sia per a bandejar definitivament allò de què tenim aversió.

Trec a col-lació aquestes obvietats per referir-me a una nova interpretació de Llull, que anomenaré lul-lisme secular, els representants de la qual tendeixen a mostrar-se com a defensors d'una manera ideològicament neutra, religiosament desinteressada, és a dir, una manera objectiva i, doncs, científica, d'accedir al pensament de Llull. Que els lul-listes seculars hagin fet aportacions importants en crítica històrica o en precisions textuals, és un fet que ningú no pot negar. ${ }^{8}$ Tanmateix, voldria fer veure que els lul-listes seculars parteixen d'uns pressupòsits interpretatius la validesa dels quals no és, ni de lluny, inqüiestionable. D'altra banda, fa uns anys, aparegué una publicació inversemblant, degudament apadrinada per conspicus lul-listes seculars que tàcitament donaven entenent que les desconcertants hipòtesis de la publicació eren tesis demostrades. Doncs bé, també voldria fer veure que aquest apadrinament acrític permet de sospitar legítimament que el rigor científic que empren els lul-listes seculars no sempre és tan irreprotxable com ells s'afiguren, especialment quan es tracta de discutir el lloc que correspon a Llull en la història del pensament.

\section{LA IDEOLOGIA DEL LUL·LISME SECULAR}

Fa una desena d'anys, arran d'un afer eclesiàstic —el procés canònic de la beatificació de Llull—, el periodista Bartomeu Homar Bestard demanà a Anthony Bonner si convenia separar el Llull religiós del Llull intel-lectual. ${ }^{9}$ La resposta de Bonner fou prou clara: «Encara que Llull mai no separà la teologia de la filosofia i deia que els coneixements constitueixen una unitat, crec que en la moderna visió de Llull han d'anar per camins separats.» No crec que Anthony Bonner hagi rectificat aquesta declaració de principis:

1) històricament sabem que Llull no separava la teologia i la filosofia;

2) avui, però, convé separar-les quan estudiem el seu pensament.

${ }^{6}$ Hans-Georg Gadamer, Wahrheit und Methode (Tübingen: Mohr-Siebeck, 1975) p. 304: «Der Anspruch auf völlige Vorurteilslosigkeit ist eine Naivität».

7 Gadamer, Wahrheit und Methode, citat supra, pp. 298-299: «Der Zirkel des Verstehens ist also überhaupt nicht ein methodischer Zirkel, sondern beschreibt ein ontologisches Strukturmoment des Verstehens».

8 Josep M. Ruiz Simon, «Per comprendre l'Art de Ramon Llull. L'aportació d'Anthony Bonner», Els Marges, 87 (2009) 65-72.

9 «Anthony Bonner: Lul-lista. "Debemos separar el Llull religioso del intelectual"», entrevista signada per Bartomeu Homar Bestard, El Mundo - El dia de Baleares (27, novembre, 1998) p. 83. 
No sé si Bonner ha explicat mai per què cal separar la teologia i la filosofia quan estudiem un autor que precisament sostenia que no s'havien de separar. L'única explicació que provisionalment em sembla plausible és que Bonner deu ésser del parer que el Llull «religiós» (el qui vol mantenir unides la fe i la raó) avui dia manca d'interès, mentre que un Llull «areligiós» —-sorprenentment, Homar en diu «intel-lectual»-, és a dir, un Llull els raonaments del qual serien vàlids al marge de la fe cristiana que els inspirà, té encara interès per al lector secular actual.

És clar que es tracta d'una entrevista periodística i el gènere no es caracteritza pas pel rigor expositiu. La necessitat de cridar l'atenció podria haver modificat les declaracions. Però, un any abans, en una publicació científica, Anthony Bonner havia escrit un article que no sols no contradiu allò que afirmà en l'entrevista, ans s'hi harmonitza bé. ${ }^{10}$ Amb tota objectivitat, Bonner hi exposava que el projecte de Llull era apologètic — la conversió de sarraïns i jueus - i que la consecució d'aquest objectiu havia obligat Llull a recórrer a la teologia, a la ciència i a l'ètica per tal de produir arguments irrefutables. ${ }^{11}$ Però, tot i haver admès que la teologia i l'ètica són elements inherents al projecte lul-lià, l'article les negligeix, i Bonner presenta els aspectes matemàtics de la lògica subjacent a l'Art (combinatòria, grafs...) com si fossin allò que realment interessava a Llull (what Llull was up to). ${ }^{12}$

A la fi de l'article i davant la possibilitat —no gens negligible- que un lector actual trobi irrellevants les vagues aportacions matemàtiques de Llull, Bonner fa una comparació sorprenent. Si algú ens demanava per a què serveix avui dia l'Art de Llull, hauríem de fer com aquell naturalista expert en aràcnids que, quan li preguntaren per a què servia estudiar les aranyes, respongué: «Tant se val per a què serveixi estudiar-les! Al capdavall, és tan interessant de poder-ho fer! $\gg^{13}$ No sabem, doncs, si serveix de gaire estudiar l'Art lul-liana, però és tan interessant de poder-ho fer! Les doctrines teològiques i filosòfiques, inherents a l'Art lul-liana, sobre el món, l'home i la divinitat interessen relativament poc, o gens. ${ }^{14}$ Allò que és interessant de debò es troba en la manera com Llull expressa

${ }^{10}$ Anthony Bonner, «What was Llull up to?», dins Transformation-Based Reactive Systems Development. 4th International AMAST Workshop, M. Bertran (ed.) (Berlín - Heidelberg - Nova York: Springer, 1997) pp. 1-14 (Lecture Notes in Computer Science, vol. 1231).

${ }^{11}$ Bonner, «What Was Llull up to?», citat supra, p. 3: «What Llull then set out to do was to show how one could combine these theological, scientific and moral components to produce arguments that at least couldn't be rejected outright by his opponents.»

${ }^{12}$ Certament, cal tenir en compte que l'article forma part d'una publicació científica. El que sorprèn no és, doncs, que parli dels elements matemàtics subjacents a l'Art, ans que hi siguin presentats tàcitament com allò que realment interessava a Llull.

${ }^{13}$ Bonner, «What Was Llull up to?», citat supra, p. 13 : «The basic problem, as I see it, is that here we have inherited an ancient computer made of parchment and ink, but along the way the manual got lost. We have many of the materials to make a new one, and if you ask, what use would it be, I would answer what a professor from New York University answered some years ago. He was an arachnologist, and when a reporter asked him what good spiders were, he replied, 'Spiders are damned interesting, that's what good spiders are'.»

${ }^{14}$ En aquest sentit em sembla un encert que Raimundus Lullus. An Introduction to his Life, Works and Thought, A. Fidora i J. E. Rubio (ed.) (Turnhout: Brepols, 2008) hagi dedicat, al marge 
les seves idees, és a dir, està en els elements lògics de què es val el seu discurs. De Llull no interessa què diu, sinó la manera lògica com ho diu. ${ }^{15}$

Em costa d'imaginar-me un estudiós de cap gran pensador (Plató, Agustí, Spinoza, Hegel...) que sostingui que ell només el llegeix perquè li plau la manera lògica com s'expressa i que tant li fa allò que pugui dir. Crec que passa tot al contrari, hom llegeix i estudia un clàssic perquè considera que té coses a dir. No cal estar-hi d'acord en tot. Fins és possible de dissentir-hi gairebé en tot. L'important és que l'estudiós se senti interpel-lat per les idees que descobreix en la lectura; el fonamental és que el lector se senti qüestionat per les propostes que hi llegeix. Un clàssic mai no deixa indiferent els seus lectors. Per als lul-listes seculars, en canvi, tant se val allò que Llull hagi volgut dir —o, en tot cas, això no és pas el més interessant—, l'important és que ens hi puguem entretenir.

N'és un bon exemple la declaració que Josep M. Ruiz Simon féu en la seva contribució a unes jornades sobre Llull. ${ }^{16}$ Amb una certa despreocupació Bonner havia comparat l'opus lul-lià amb una aranya, un vivent el comportament del qual pot ésser interessant d'estudiar. Ruiz Simon, menys cautelós i més enterc, compara el pensament de Llull amb un ens inert, amb un fòssil ${ }^{17}-\mathrm{O}$ amb un cadàver, si tant convé. ${ }^{18}$ La tria de les imatges no és irrellevant. La distància entre l'observador i la cosa observada augmenta. Per si mateix, un vivent petrificat —o un cos cadavèric, tant se val— no té cap sentit, només en té si un paleontòleg cultural, si es tracta d'un fòssil ideològic, o un forense filosòfic, si es tracta d'un cadàver conceptual, li confereix un poder explicatiu dins el sistema de pensament amb què ell interpreta les dades.

Ruiz Simon s'adhereix a la creença, bàsica en la seva ideologia secular, que com més augmenta la distància entre l'intèrpret i l'obra interpretada, com més gran és la desconfiança que l'intèrpret té envers l'obra que pretén interpretar,

de les dades imprescidibles (vida i obres), dues terceres parts de l'espai disponible a exposar les idees de Llull sobre l'home, el món i Déu, i només una tercera part a l'exposició del funcionament de l'Art.

${ }_{15}$ Aquest programa, centrat exclusivament en la forma d'un pensament —el contingut del qual no és negat ni criticat, sinó metodològicament marginat- persisteix deu anys després en la seva darrera publicació: Anthony Bonner, The Art and Logic of Ramon Llull. A User's Guide (LeidenBoston: Brill, 2007), p. IX: «This is a book about method, not content; about the how, not the what». Tanmateix, Bonner matisa tot seguit la frase i admet la importància de la matèria en la configuració de la forma.

16 Josep M. Ruiz Simon, «El Joc de Ramon Llull i la significació de l'Art General», dins Ars Brevis (Barcelona: Universitat Ramon Llull, 1998), pp. 55-65.

17 Parlant de la presumpta vigència del pensament de Llull, Ruiz Simon, «El Joc de Ramon Llull», citat supra, p. 56, precisa: «Dic 'presumpta' perquè per bé que les hipotètiques bones intencions ecumèniques universals de Llull puguin, potser, formar part d'algun patrimoni sentimental encara vigent, la seva proposta filosòfica, l'Art General, pertany, al meu entendre, al que Paolo Rossi va denominar fa anys, a propòsit de les arts de la memòria, la "categoria dels fòssils intel·lectuals'».

${ }_{18}$ Declaracions de Ruiz Simon recollides per Josep Massot, «Ruiz Simon reconstruye cómo creó Llull un sistema filosófico que subvirtió el de su época », La Vanguardia, 3, desembre, 1999: «Pero, de hecho, al inicio del proyecto de este libro [L'Art de Llull i la teoria escolàstica de la ciència] también había un cadáver o, más concretamente, un fósil: el pensamiento de Llull.» 
més garanties hi ha d'imparcialitat i de clarividència. Prosseguint en aquesta orientació hermenèutica del lul-lisme secular caldria dir que el daltonià és qui millor pot apreciar els colors, i el desafinat qui millor pot distingir els intervals. Els lul-listes seculars pensen que la syntonía i la sympátheia amb el text són sempre un destorb, diguin el que diguin els hermeneutes. ${ }^{19}$ En aquest sentit, la filosofia de Llull, per si mateixa mancada d'interès —un fòssil insignificant o un de tants cadàvers que deixa enrere el curs de la història-, només pot arribar a tenir algun valor històric si un lul-lista secular - això és, un paleontòleg cultural o un forense expert en despulles conceptuals, com és ara Ruiz Simon-, es digna a interpretar-la com una baula perduda en l'evolució del pensament humà. ${ }^{20}$

La declaració ideològica de Ruiz Simon, no sols no sorprengué ningú, ans suscità l'aprovació entusiasta de la seva mentora, Lola Badia, la qual cosa vol dir, al meu criteri, que el lul-lisme secular era una ideologia compartida. L'entusiasme acrític fa que Lola Badia atribueixi a Paolo Rossi una opinió que l'historiador italià reservava per a les arts de la memòria i la combinatòria de l'època barroca, i que només Ruiz Simon havia aplicat concretament a Ramon Llull: ${ }^{21}$ «Admetre que, en paraules de Paolo Rossi, l'Art de Ramon pertany a la categoria dels "fòssils intel-lectuals" no hauria de bloquejar-ne l'estudi. Ans al contrari, si no li hem de buscar cap connexió immediata amb els debats que alimenten les discussions contemporànies, podrem aprendre a conèixer millor el Llull que "juga amb habilitat, en favor de la seva proposta epistemològica, amb les mateixes cartes textuals amb què jugaven els seus contemporanis de París o d'Oxford"». ${ }^{22}$ D'un enèrgic cop de ploma, Lola Badia dóna per fet que:

1) l'Art de Llull no té res a dir al lector actual: «no té cap connexió immediata amb els debats que alimenten les discussions contemporànies»;

2) però sí que tenia coses a dir als pensadors del seu temps: els presentà una «proposta epistemològica» i ho féu «amb les mateixes cartes textuals amb

${ }^{19}$ Gadamer, Wahrheit und Methode, citat supra, p. 300: «Die Hermeneutik muß davon ausgehen, daß wer verstehen will, mit der Sache, die mit der Überlieferung zur Sprache kommt, verbunden ist und an die Tradition Anschluß hat oder Anschluß gewinnt, aus der die Überlieferung spricht. [...] Es besteht eine Polarität von Vertrautheit und Fremdheit, auf die sich die Aufgabe der Hermeneutik gründet. [...] In diesem Zwischen ist der wahre Ort der Hermeneutik».

${ }^{20}$ Ruiz Simon, «El Joc de Ramon Llull», citat supra, p. 56: «[La filosofia de Llull] és una espècie extinta, una filosofia morta, un artefacte epistemològic que no és susceptible de ser integrat en els debats filosòfics contemporanis. Però això no vol dir que, considerada en el seu context, no sigui una proposta valuosa, ni tampoc que pugui ser ignorada pels historiadors de la filosofia. L'estudi dels fòssils naturals permet als zoòlegs i els botànics d'aprendre moltes coses sobre l'evolució de les especies i sobre la constitució actual dels seus individus. Crec que passa una cosa semblant amb l'estudi dels fòssils intel-lectuals. L'Art General de Llull és una important baula perduda en la cadena, o millor dit, en una de les cadenes que configuren l'evolució del pensament filosòfic.»

${ }^{21}$ Paolo Rossi, Clavis universalis. Arti della memoria e logica combinatoria da Lullo a Leibniz (Bolonya: Il Mulino, 1983), p. 5: «Le arti della memoria e la logica combinatoria appartengono, senza alcun dubio, alla categoria del fossili intellectuali».

${ }^{22}$ Lola Badia, recensió de «Ruiz Simon, "El joc de Ramon Llull i la significació de l'Art General"», SL 42 (2002) p. 132. 
què jugaven els seus contemporanis de París o d'Oxford», una proposta que els lul-listes seculars tenen per convincent.

Qui redacta aquestes ratlles té una opinió contrària:

1) pensa que, sense precisar la interpretació que hom fa de l'Art, no es pot afirmar categòricament que avui no interessa ningú;

2) sosté que és del tot inversemblant la tesi de Josep M. Ruiz Simon segons la qual Llull, jugant amb les mateixes cartes que els aristotèlics de l'època, hauria resolt amb l'Art les grans qüestions — «totes», precisaran acríticament Lola Badia i Lluís Cabré - debatudes pels epistemòlegs escolàstics.

La ideologia del lul-lisme secular, tal com la pressuposa metodològicament Anthony Bonner, l'ostenta provocadorament Ruiz Simon, l'aprova incondicionalment Lola Badia i l'accepten acríticament Albert Soler i Lluís Cabré, sembla que es basa en un doble pressupòsit:

1) d'una banda, l'Art, presa en la seva totalitat, com a empresa apologètica cristiana, alhora teològica i filosòfica, és obsoleta i cal desestimar-la sense pal-liatius;

2) d'altra banda, l'Art, degudament reduïda a «una eina» conceptual —a un «artefacte epistemològic», diu Ruiz Simon-, «pot respondre d'una vegada totes les preguntes que es formulava l'escolàstica en les seves inacabables disputes». ${ }^{23}$

Tal com l'entén el lul·lisme secular, doncs, l'Art només té validesa en la mesura que pot representar una de les baules perdudes en la cadena evolutiva del pensament, amb el benentès que un lul-lista secular, competent en història de la filosofia, estarà del tot capacitat per a fer-ho. Sorprèn la seguretat amb què els lul-listes seculars ignoren el problema hermenèutic. ${ }^{24}$ Segurament, per a Ruiz Simon l'hermenèutica de Gadamer és una romanalla més de les moltes que guarda el «patrimoni sentimental encara vigent». ${ }^{25}$

Això no treu que, quan convingui, els lul-listes seculars puguin posar irresponsablement en mans de Llull aquest artefacte epistemològic, degudament perfilat en les seves darreres versions, per tal que li pugui servir d'arma espiri-

${ }^{23}$ Badia, recensió de «Ruiz Simon», citat supra, p. 132.

${ }^{24}$ Segons l'hermenèutica de Gadamer, interpretar vol dir resoldre racionalment la tensió produïda per la polaritat «confiança-estranyesa» (Vertrautheit-Fremdheit) envers l'obra que hom vol interpretar, una tensió que es dóna sempre a l'interior d'una tradició — que, evidentment, hauria d'ésser la cristiana quan es tracta d'interpretar l'Art lul-liana-; cf. Gadamer, Wahrheit und Methode, citat supra, p. 300, text citat supra, nota 14. El lul-lista secular no té cap confiança en l'obra de Llull, en té prou de sentir estranyesa envers els escrits lul-lians per a creure's capacitat per a interpretar-los. Segons el meu parer, aquesta suficiència que gasten els lul-listes seculars limita extraordinàriament llur capacitat interpretativa.

${ }^{25}$ Ruiz Simon, «El Joc de Ramon Llull», citat supra, p. 56, nota 13. 
tualment letal, i així pugui dur a terme les seves inconfessables i pèrfides intencions. Car com diu Ruiz Simon i subscriu Albert Soler: «El Doctor Il-luminat mai no va deixar de pensar la seva Art com una arma de conversió massiva al servei de l'eliminació de l'islam i de la cristianització de tota la humanitat. I si la primera de les seves concrecions literàries va ser concebuda com un manual per a una escola de missioners situada en un paisatge apartat i idíl-lic, l'Ars generalis ultima i la seva versió portàtil, l'Ars brevis, van ser pensades com a armes espirituals indispensables per als croats que havien de conquerir, per la força de les armes materials, i en el context d'una gran operació bèl-lica per terra i per mar, els dominis dels "infidels".» ${ }^{26}$

Tothom sap que l'actitud de Llull enfront de la croada fou més ambigua del que un pacifista actual hauria desitjat, però afirmar sense matisos que les darreres versions de l'Art «van ser pensades com a armes espirituals indispensables» per a «eliminar l'islam», no sembla pas un judici gaire equànime.

\section{L'ART COM A ARTEFACTE EPISTEMOLÒGIC}

El producte més representatiu i més brillant del lul-lisme secular és, sens dubte, l'estudi de Josep M. Ruiz Simon sobre l'Art lul-liana, interpretada com una resposta epistemològica a la concepció escolàstica de la ciència. ${ }^{27}$ L'obra d'Anthony Bonner, The Art and Logic of Ramon Llull, ja esmentada, podria ésser considerada com la metodologia subjacent a la tesi de Ruiz Simon, car els elements religiosos s'hi fan fonedissos i l'epistemologia pren tot el protagonisme: la secularitat racional en estat pur. Ruiz Simon ens presenta un Llull que, amb uns quants retocs, hauria pogut publicar perfectament la seva Ars brevis en un dels volums de la International Encyclopedia of Unified Science. Al capdavall, segons Ruiz Simon, els interessos eren gairebé els mateixos,$^{28}$ perquè quan ell creu que ha d'interpretar l'Art amb l'ajut d'autors posteriors als medievals, no té necessitat de recórrer a cap lògica metafísica ${ }^{29} \mathrm{i}$ encara menys a cap filosofia

${ }^{26}$ Josep M. Ruiz Simon, «L'evangeli de la ciència universal», dins Ramon LLull. Història, pensament i llegenda (Barcelona: Fundació la Caixa, 2008), p. 44; la mateixa idea és represa a Josep Maria Ruiz i Albert Soler, «Vida, pensament i context de Ramon Llull», Catalan Historical Review 1 (2008), p. 202. Dos deixebles de Louis Althusser, ja havien vinculat l'Art lul-liana amb l'ideal de croada; cf. Étienne Balibar i Pierre Macherey, art. «Dialectique», dins Encyclopaedia Universalis. Dictionnaire de la Philosophie (París: Encyclopaedia Universalis - Albin Michel, 2000), p. 402: «À la fin du XIII e siècle l'Ars generalis de Raymond Lulle proposera une technique générale du raisonnement propre à defendre les croisés contre les arguments des infidèles.»

27 Josep M. Ruiz Simon, L'Art de Llull i la teoria escolàstica de la ciència (Barcelona: Quaderns Crema, 1999).

${ }^{28}$ El tema del primer volum del gran projecte neopositivista era: «Foundations of the unity of science», precisament l'objectiu que, segons Ruiz Simon, perseguia l'Art lul·liana.

${ }^{29}$ Georg Wilhelm Friedrich Hegel, Wissenschaft der Logik (Hamburg: Meiner, 1995), 4 vols.; Francis Herbert Bradley, The Principles of Logic (Londres: Oxford University Press, 1922), 2 vols.; Hermann Krings, Transzendentale Logik (Munic: Kösel, 1964); Leo Gabriel, Integrale Logik (Viena: Herder, 1965). 
de la religió, ${ }^{30}$ recorre esbiaixadament a Leibniz ${ }^{31} \mathrm{i}$, encara que no vingui gaire a tomb, a Imre Lakatos, un teòric de la ciència. ${ }^{32}$

Gràcies al seu caràcter insòlit i provocador, com també a la habilitat periodística «de tall impressionista ${ }^{33}$ amb què era presentat, el llibre de Ruiz Simon, farcit de citacions desconcertants, aconseguí d'enlluernar els desprevinguts i provincians lectors catalans. L'obra fou candorosament ben acollida a la premsa ${ }^{34} \mathrm{i}$ rebé crítiques favorables en revistes especialitzades catalanes i mallorquines, amb les matisacions acadèmiques pertinents que de cap manera no en qüestionaven la tesi. ${ }^{35}$ En contraposició a aquesta cofoia acollida casolana, els lectors de la resta del món - mai tan ben dit—optaren per ignorar l'obra. Ni una sola crítica en cap revista de filosofia medieval. ${ }^{36}$ No és inversemblant que es pugui tractar d'un silenci educat que els lul·listes seculars mai no agrairan prou. ${ }^{37}$

30 Alfred North Whitehead, Religion in the Making (Nova York: Macmillan, 1926); Maurice Bondel, L'action (París: PUF, 1949), 2 vols.; La philosophie et l'esprit chrétien (París: PUF, 1950), 2 vols.; Henry Duméry, Philosophie de la religion (París: PUF, 1957), 2 vols.

${ }^{31}$ Ruiz Simon cita Yvon Belaval, Leibniz critique de Descartes (París: Gallimard, 1960), que, pel que he pogut comprovar, no té en compte per a res l'Art lul-liana; però no cita les pàgines que Tomàs i Joaquim Carreras Artau, Historia de la filosofía española. Filosofía cristiana de los siglos XIII al XV (reedició, Barcelona-Girona: IEC - Diputació de Girona), vol. 2, pp. 313-317, dediquen al lul-lisme de Leibniz; tampoc no cita Erhard-Wolffram Platzeck, «Gottfried Wilhelm Leibniz y Raymundo Llull», EL 16 (1972) pp. 129-193, que en depèn. Ruiz Simon ignora, és clar, tot allò que de religiós hi pot haver en Leibniz; cf. Maria Rosa Antognassa, «Die Rolle der Trinitäts und Menschwerdungsdiskussionen für die Enstehung von Leibniz’ Denken», Studia Leibnitiana 26 (1994) 525550. Posteriorment la mateixa autora ha publicat, Trinità e Incarnazione. Il rapporto tra filosofia e theologia revelata nel pensiero di Leibniz (Milà: Vita e Pensiero, 1999).

${ }^{32}$ Imre Lakatos, «The Method of Analysis-Syntesis», dins Mathematics, Science and Epistemology (Cambridge: Cambridge University Press, 1980), pp. 70-103. Ruiz Simon, L'Art de Llull, s'hi refereix extensament, citat supra, pp. 213-214 i 221-224.

33 Aplico a Ruiz Simon la mateixa expressió amb què ell criticà Miquel Batllori en la ressenya «[100] Ramon Llull, Antologia Filosòfica», Llengua \& Literatura 1 (1986) p. 575. Ruiz Simon tendeix a impressionar el lector amb tot un reguitzell de citacions que desconcerten per llur heterogeneïtat. Examinades atentament de la vora, les citacions de Ruiz Simon revelen llur puntillisme impressionista, es manifesten inconnexes i perden poder probatori global.

${ }^{34}$ Josep Massot, «Ruiz Simon reconstruye cómo creó Llull un sistema filosófico que subvirtió el de su época», La Vanguardia, 3, desembre, 1999; Albert Soler, «Ramon Llull, la autoridad alternativa», La Vanguardia (11, febrer, 2000); Xavier Filella, «L'Art alternativa de Ramon», Avui (17, febrer, 2000).

35 Lluís Cabré, SL 40 (2000) pp. 189-193; Josep Perarnau, Arxiu de Textos Catalans Antics 19 (2000) pp. 690-694; Antoni Bordoy, Taula. Quaderns de pensament 37 (2002) pp. 161-163. Malgrat els acadèmics qüestionaments marginals de la recensió, Lluís Cabré no amaga la seva adhesió a la tesi i, pel que sembla, també al lul-lisme secular: «La hipòtesi de Ruiz Simon proposa un Llull normal, 'amb fonts', en un doble sentit: com a creador d'un sistema epistemòlogic que pretenia eixugar tots els dèficits de la teoria de la ciència llavors vigent (cosa que implica, és clar, que l'havia estudiada abans i, probablement, que la seguia assimilant mentre anava polint l'Art); i com a hàbil estratega que utilitzava pro domo sua algunes peces de la teoria que volia superar, per tal de legitimar, a ulls de l'estament acadèmic, la seva alternativa.»

${ }^{36}$ Només en dues revistes filològiques he sabut trobar: l'elogi incondicional que en fa Anthony Bonner, «Recent Scholarship on Ramon Llull», Romance Philology, 54 (2001), pp. 383-384; i la recensió més ponderada de Juan Carlos Bayo, Bulletin of Hispanic Studies, 78 (2001) 644-645. 
Tanmateix, aquest silenci dels medievalistes hauria d'haver fet reflexionar els lul-listes seculars, ja que la tesi de Ruiz Simon era esborronadorament agosarada: pretenia demostrar ni més ni menys que, al tombant del segle XIV, Llull havia presentat una innovadora epistemologia que superava completament les grans mancances —-segons Lola Badia, responia «totes» les qüestions; segons Lluís Cabré, eixugava «tots» els dèficits— de la lògica aristotèlica, $i$, allò que és més important, ho havia fet utilitzant el mateix sistema d'Aristòtil. ${ }^{38}$ En el segle XIV cap lògic escolàstic no s'adonà del valor d'aquella inimaginable proposta lul-liana - almenys no ens consta—; en el segle xx cap historiador de la lògica medieval no n'havia reconegut la importància —almenys no ho he pogut llegir en cap estudi solvent. La troballa de Ruiz Simon era, doncs, sensacional.

La crítica que tot seguit faré a la tesi de Ruiz Simon es basa en el meu prejudici heurístic segons el qual és inadmissible que una tesi aparentment revolucionària es fonamenti en supòsits inversemblants. No pretenc demostrar res -l'onus probandi incumbeix a qui formula la tesi-, només vull fer veure per què considero inversemblants els fonaments de la tesi. Em limitaré, doncs, a assenyalar quatre pressuposicions desenraonades que Ruiz Simon utilitza com a suport de la seva tesi. Són les següents:

1) la pressuposició tàcita que Llull conegué a fons la logica nova aristotèlica;

2) l'admissió no provada que al tombant del segle XIV hi hagué un ampli debat de fundamento scientiarum $i$ de arte inveniendi en el qual Llull hauria intervingut amb una proposta convincent;

3) l'aceptació de donar per fet que en aquest suposat debat l'epistemologia lul-liana era capaç de reemplaçar la teoria aristotèlica de la ciència;

4) la interpretació del pròleg a l'Ars generalis ultima com si Llull hi justifiqués la seva Art com una proposta epistemològica estrictament filosòfica.

\subsection{Llull i la logica nova aristotèlica}

Els estudiosos semblen estar d'acord que cal anar molt en compte quan es tracta de precisar les fonts del pensament de Llull, especialment si l'atribució d'influències rebudes es fa mitjançant una suposició tàcita. Ens falten dades i no podem fer volar coloms. Tanmateix, Ruiz Simon no ha estat gens cautelós en aquest aspecte. Si hagués llegit un treball de Charles Lohr sobre la teoria de la

\footnotetext{
${ }^{37}$ No veig pas impossible que més d'un medievalista sorneguer hagi pogut titllar l'assaig de novel-la històrica filosòficament mal escrita, car, com deien els escolàstics: «Quod nimis probat, nihil probat».

${ }^{38}$ Ruiz Simon, L'Art de Llull, citat supra, pp. 12-13: «L'artefacte epistemològic lul-lià és fet, sobretot, amb les mateixes peces (conceptes, consideracions, subteories) que la teoria de la ciència aristotèlico-escolàstica i sense conèixer quina era la morfologia i la funció d'aquestes peces és impossible d'entendre l'operació de reciclatge a què les sotmet el Doctor Il-luminat.»; p. 273 nota 336, on es parla de «la centralitat que la teoria aristotèlica de la demostració té en l'obra de Llull».
} 
demostració en Ramon Llull, hauria conegut una opinió que li hauria estat d'allò més instructiva a l'hora d'orientar enraonadament la seva recerca sobre l'epistemologia lul-liana. Segons Lohr, «Llull, si bé conegué i utilitzà les Summulae logicales de Pere Hispà, no mostrà gaire interès pels nous tractats que els llatins havien afegit al corpus aristotèlic». ${ }^{39}$

Sembla, doncs —si més no, hom diria que és la hipòtesi més versemblant-, que l'Art arrencà de dues grans fonts: d'una banda, la lògica d'Algatzell $\mathrm{i}$ les antologies que transmetien doctrines aràbigues comunes, ${ }^{40} \mathrm{i}$, de l'altra, la logica vetus coneguda sobretot a través de les Summulae logicales de Pere Hispà i d'algun dels altres tractats escolars en boga.${ }^{41}$ Un cop estructurada, l'Art podria haver rebut influxos tangencials de textos sorgits arran de la difusió de la logica nova,${ }^{42}$ però Llull, convençut de posseir ja un sistema prou sòlid de pensament, no hauria participat en el complex treball de recepció dels nous tractats aristotèlics que precisament qüestionaven el seu sistema: Analytica priora, Analytica posteriora, Libri topicorum, Libri elenchorum. Difícilment, doncs, Llull hauria pogut intervenir amb competència en cap debat que pressuposés el coneixement a fons de textos aristotèlics dels quals ell només tenia una informació superficial. $^{43}$

Si admetíem aquest plantejament, el primer treball que hauria d'haver fet Ruiz Simon hauria d'haver estat la demostració que Llull estava familiaritzat amb els tractats de la logica nova, perquè els havia llegit i els havia estudiat.

39 Charles Lohr, «Ramon Llull's Theory of Scientific Demostration», dins Argumentationstheorie. Scholastische Forschungen zu den logischen und semantischen Regeln korrekten Folgerns, K. Jacobi (ed.) (Leiden: Brill, 1993), p. 729: «Although Lull certainly knew and used the 'Summulae logicales' of Peter of Spain, he showed little interest in the new tracts which the Latins had added to Aristotle.» Cal no oblidar que Lohr és un expert en la difusió de l'aristotelisme en l'Occident llatí.

${ }^{40}$ Hansjürgen Verweyen, Philosophie und Theologie (Darmstadt: Wissenschaftliche Buchgesellschaft, 2005), p. 213: «Es scheint, daß die genaue Erschließung des für Lulls Ars spezifischen Denkens zu einem guten Teil von Fortschritten auch in der Erforschung der islamischen Gelehrsamkeit seiner Zeit abhängt.»

${ }^{41}$ En el segle XIII els textos més difosos eren: Guillem de Sherwood, Introducciones in logicam, C. Kann (ed. llatí-alemany) (Hamburg: Meiner, 1995); Lambert d'Auxerre, Summa lamberti, F. Alessio (ed.) (Milà, La Nuova Italia, 1971); Roger Bacon, Summulae dialectices, A. de Libera (ed.), dins AHDLMA 53 (1987) pp. 139-289; 54 (1988) pp. 171-278.

${ }^{42}$ Per exemple, en la redacció de la seva Logica nova — «nova» perquè era basada en l'Art, no perquè incorporés els tractats de la logica nova aristotèlica - Llull podia haver pres elements de resums escolars en boga; cf. Alexander Fidora i Guilherme Wyllie, «Ramon Llull i el tractat 'De fallaciis' del pseudo-Tomàs d'Aquino», Enrahonar 42 (2009) pp. 11-19.

${ }^{43}$ Segons Jocelyn N. Hillgarth, la formació inicial de Llull fou molt limitada en filosofia escolàstica; cf. «The Attitudes of Ramon Llull and of Alfonso X of Castile to Islam », dins Actas del V Congresso Internacional de Filosofía Medieval (Madrid: Editora Nacional, 1979), vol. 2, p. 827: «Llull's knowldge of contemporary scholastic thought was rudimentary compared to the thorough grounding he possessed in Islamic logic, philosophy and religion.» Tanmateix, podem pressuposar que, arran de les seves estades a Montpeller i París, Llull s'esforçà per subsanar aquesta mancança inicial. Ruiz Simon hauria hagut de precisar el pressumible l'abast d'aquest esforç. Però hom no pot donar per fet que, des de sempre, Llull estigué familiaritzat amb la lògica aristotèlica que dominaven els seus conrtemporanis. 
Ruiz Simon ho havia de fer per tal com sembla més probable que no els estudià que no pas que els conegué a fons. Doncs bé, res d'això. ${ }^{44}$ Sense ni tan sols plantejar-se el problema, Ruiz Simon parteix tàcitament del supòsit que Llull no sols coneixia a fons els tractats de la logica nova, ans també coneixia bé allò que debatien els magistri artium i els teòlegs escolàstics del seu temps. ${ }^{45}$

Sense una base històrica fiable que demostri que Llull havia estudiat profundament i coneixia perfectament les possibilitats i les mancances de la teoria aristotèlica de la demostració científica, esdevé il-lusòria la tesi de Ruiz Simon de convertir l'Art en un text epistemològic que resol els problemes que debatien els magistri artium capficats en la interpretació i l'assimilació dels textos de la logica nova. Les dades de què avui disposem — canvis continus en la formulació de l'Art i queixes sovintejades de la incomprensió i l'animadversió dels contemporanis escolàstics - més aviat fan suposar el contrari del que s'afigura Ruiz Simon: el problema que tenia Llull no era com «imposar-se» al caràcter defectiu de lògica aristotèlica del seu temps, sinó com «oposar-se» als embats de les exigències lògiques dels seus contemporanis, acomodant-hi la seva Art, sense desvirtuar-la. ${ }^{46}$

\subsection{Els suposats debats De fundamento scientiarum $i$ De arte inveniendi}

No crec pas que a partir de la simple exposició de les dificultats teòriques amb què topa una scientia universalis aristotèlica - minuciosament assenyalades per Pierre Aubenque, un especialista en la filosofia d'Aristòtil però que, cal recordar-ho, no és cap estudiós de l'aristotelisme medieval, — ${ }^{47}$ es pugui donar per fet que la qüestió de unitate scientiarum o de fundamento scientiarum era un tema central en els debats dels lògics medievals. Certament, en la segona meitat

${ }^{44}$ Ruiz Simon no demostra amb dades històriques que Llull estudià i conegué a fons la logica nova, però tampoc no aporta cap demostració rigorosa que obligui a admetre que l'Art és incomprensible si el seu autor no hagués estat un bon coneixedor de la logica nova. Cal tenir present que és del tot possible interpretar l'Art a partir de les doctrines lògiques que figuren en l'obra de Pere Hispà, el qual certament no conegué la logica nova; cf. Lambertus M. de Rijk, «Introduction» a Peter of Spain, Tractatus called afterwards Simmule logicales (Assen: Van Gorcum, 1972), p. XCII. Això no obstant, Ruiz Simon, sense fornir cap prova, dóna per fet que Llull conegué la logica nova perquè aquesta assumpció és necessària per a la tesi que ell sosté: Llull superà les anomalies que detectava en la ciència escolàstica del seu temps.

${ }^{45}$ La recensió de Lluís Cabré a SL 40 (2000), citat supra, p. 190, ho accepta com un pressupòsit necessari: «La hipòtesi de Ruiz Simon proposa un Llull [...] creador d'un sistema epistemòlogic que pretenia eixugar tots els dèficits de la teoria de la ciència llavors vigent (cosa que implica, és clar, que l'havia estudiada abans i, probablement, que la seguia assimilant mentre anava polint l'Art)».

46 Jordi Gayà, «Introducció» a Ramon Llull, Darrer llibre sobre la conquesta de Terra Santa (Barcelona: Proa, 2002) p. 46: «El punt més dèbil del sistema lul-lià era el d'acomodar a les exigències de la lògica contemporània el seu propi sistema de demostració, sense renunciar a les seves tesis bàsiques».

${ }^{47}$ Pierre Aubenque, Le problème de l' être chez Aristote (París: PUF, 1994); cf. Ruiz Simon, L'Art de Llull, citat supra, p. 13. 
del segle XIII, la recepció dels Analytica posteriora estimulà la discussió sobre la natura dels arguments demostratius $\mathrm{i}$, consegüentment, sobre el caràcter de la ciència en general, però això no eximeix Ruiz Simon d'aportar proves que demostrin que «en el context de l'ordo scientiarum escolàstic» es produí un mena de debat de fundamento scientiarum que donà lloc a una decisiva «proposta epistemològica lul-liana» unificadora de totes les ciències. ${ }^{48} \mathrm{~A}$ més d'esmentar la problemàtica inherent a la subalternatio tomista, Ruiz Simon, fa referència a altres textos contemporanis sobre aquesta qüestió però que, en no tenir cap relació entre si, no permeten pressuposar cap debat general sobre el tema. D'altra banda, com que no és gens clar que Llull els conegués, es fa molt difícil de dir en quina mesura s'hi enfrontà. ${ }^{49}$ Per tot plegat, em costa d'acceptar que Llull hagués pogut presentar l'Art als seus contemporanis com una teoria que havia «resolt el problema -irresolt en Aristòtil- de la fonamentació de les ciències particulars». ${ }^{50}$

Pel que sabem, els escolàstics del segle XIII discutien sobre l'estatut científic de la teologia, però no cercaven cap mathesis universalis, cap scientia scientiarum. Llull amb l'orientació religiosa de la seva Ars podia cercar aquesta ciència universal, i Ruiz Simon amb la seva ideologia secular pot aprovar aquesta cerca, però allò que no es pot fer és afirmar que el resultat de la cerca lul-liana fou una resposta als debats de l'època. ${ }^{51} \mathrm{El}$ més enraonat és suposar que els lògics del segle XIII mai no cregueren que l'Art resolgués els problemes amb què ells s'enfrontaven.

Els textos de divisione scientiarum redactats pels lògics contemporanis de Llull, malgrat allò que suggereix el títol, no tractaven pas de unitate scientiarum. La unificació sistemàtica de la ciència dividida en una pluralitat de disciplines no era cap problema àmpliament debatut. Els tractats intitulats de divisione scientiarum eren simples introduccions a l'estudi de les artes. ${ }^{52}$ Ben mirat, la manca

48 Ruiz Simon, L’Art de Llull, citat supra, pp. 69-85.

49 Robert Grosseteste, Commentarius in Posteriorum Analyticorum libros, P. Rossi (ed.) (Florència: Olschki, 1981); Robert Kilwardy, De ortu scientiarum A. G. Judy (ed.) (Londres - Toronto: British Academy - Pontifical Institute of Medieval Studies); Joan de Dàcia, Divisio scientiae A. Otto (ed.) (Copenhagen: Societas Linguae \& Litterarum Danicarum, 1955); Ulric d'Estrasburg, De summo bono, B. Mojsisch (ed.) (Hamburg: Meiner, 1989). Ruiz Simon no cita Arnulf de Provença, Divisio scientiarum i els tres tractats anònims editats dins Quatre introductions à la philosophie au XIII siècle. Textes critiques et étude historique, C. Lafleur (ed.) (Montréal-París: Institut d'études médiévales - Vrin, 1988), pp. 297-347.

${ }^{50}$ Ruiz Simon, L'Art de Llull, citat supra, p. 421.

${ }^{51}$ Els problemes candents i les qüestions debatudes a l'època eren del tot aliens als interessos intel-lectuals de Llull; cf. Philosophical Debates at Paris in the Early Fourteenth Century, S. P. Brown, Th. Dewender i Th. Kobusch (ed.) (Leiden-Boston: Brill, 2009).

52 Segons Alfred Otto, «Introduction» a Joan de Dàcia, Divisio scientiae (Copenhagen: Societas Linguae \& Litterarum Danicarum, 1955) p. XII-XIII, a mitjan segle XIII, de resultes de la influència del nou aristotelisme, la divisio scientiae o divisio philosophiae, era simplement «une forme abregée, comme un préambule méthodique à des explications des textes». Claude Lafleur, «Étapes et modes d'un enseignement philosophique au XIII ${ }^{e}$ siècle: introduire, commenter, examiner», Laval théologique et philosophique, 60 (2004) 405-407 : «La première leçon suivie par le jeune universitaire prenait normalement la forme d'une 'division des sciences'»; Quatre introductions, 
d'una teoria que unifiqués totes les ciències no era res que preocupés gaire els medievals aristotèlics — com tampoc no neguiteja gaire avui dia—, ${ }^{53}$ perquè aquesta mancança oferia també els seus avantatges: donava autonomia a cada ciència particular i concedia llibertat per a intentar trobar una nova ontologia que fos formal i universal.

Pel que fa a una nova ars inventiva estrictament demostrativa, Ruiz Simon tampoc no fa justícia a les dades històriques. Pressuposa que Ramon Llull, en solitari, hauria fet front a una antiga ars inveniendi purament conjectural, perquè només «oferia un llistat de llocs on trobar abundants arguments per concloure a través de sil-logismes dialèctics» ${ }^{54}$ La realitat sembla haver estat força més complexa. Ruiz Simon ho ignora i sembla suposar que al tombant del segle XIV l'ars inveniendi medieval consistia exclusivament a construir sil-logismes hipotètics, amb escàs valor cognoscitiu, a partir de simples llistes de llocs comuns. Tanmateix tenim motius per suposar que la comprensió que els medievals tenien d'allò que és probabile era molt més matisada.55

Els historiadors de la lògica medieval ens diuen que els Topica traduïts per Boeci, a més d'haver donat lloc a una ars inveniendi ben establerta en la retòrica, havien deixat d'ésser simples «llocs comuns» per a fer discursos probables $\mathrm{i}$, d'ençà del tractament que n'havia fet Pere Hispà, a poc a poc s'havien anat convertint en instruments lògics que confirmaven i avaluaven alhora les argumentacions. ${ }^{56} \mathrm{Al}$ marge de l'ars inventiva lul.liana, doncs, hi havia hagut en la lògi-

cit. supra, p. 145: La «raison pratique de préparer aux examens a pour pendant théorique le besoin de classifier le nouveau savoir — principalement Aristote. [...] Ce besoin de classification pourrait bien être à l'origine de certaines divisiones scientiarum.»

${ }^{53}$ C. Ulises Moulines, «The unity of science and the unity of formal science», dins Logic, Epistemology and the Unity of Science, S Rahman, J. Symons, D. M. Gabbay, J. P. Van Bendegem (ed.) (Dordrecht: Kluwer, 2004), p. 159: «At certain times they [els científics reduccionistes] seem to be on the verge of fulfilling the utopia of 'one theory - one world'. But, then, once and again some trouble-makers appear on the scene with other theories representing well other sorts of experiences and definitely not reducible to the pretended one big theory.»

${ }^{54}$ Ruiz Simon, L'Art de Llull, citat supra, p. 186.

55 Giulio d'Onofrio, Fons scientiae. La dialettica nell' Occidente tardo-antico (Nàpols: Liguori, 1984), p. 326: «Il 'probabile' non è l'ignoto, né l'erroneo o l'immaginario: è il vero che puo o deve ancora essere 'provato', sottoposto alla verifica della disciplina che distingue il vero dal falso, cioè della dialettica, fons scientiae. Ma quando probabilis diventa la scientia stessa, allora la dialettica trova in questa probabilità senza limite i termini non valicabili della sua indagine, l'ambito che l'accoglie; ed arresta allora la sua tensione dimostrativa nello svelarsi di un risultato trascendente che è nei suoi confronti esauriente e conclusivo. Con il ritorno in occidente del corpus aristotelicum nella sua integrita e la comprensione adeguata dei principi epistemologici che vi sono proposti, gli scolastici del XIII secolo realizzeranno compiutamente l'acquisizione della verita di fede come principio preliminarmente noto di ogni conoscenza scientifica in teologia, e della teologia come principio di tutte le altre scienze.»

${ }^{56}$ Boethius's De Topicis differentiis, E. Stump (trad. i ed.) (Ithaca-Londres: Cornell University Press, 1978), pp. 215-236: «Peter of Spain on the Topics»; Eleonore Stump, «Dialectic», dins The Seven Liberal Arts in the Middle Ages, D. L. Wagner (ed.) (Bloomington: Indiana University Press, 1986), p. 140: «With Peter of Spain's treatment, the Topics have virtually completed their slow metamorphosis from instruments for the discovery of arguments to instruments for the confirmation and evaluation of arguments.» Niels J. Green-Pedersen, The Tradition of the Topics in the 
ca escolàstica un lent procés d'harmonització de la teoria de la deducció necessària dels Analytica posteriora amb la teoria de l'argumentació probable dels Topica. Es tractava d'una operació treballosa de lògica modal que no era gens fàcil perquè obligava a flexibilitzar i eixamplar la noció de consequiència lògica, una reglamentació que en tots els sistemes lògics es caracteritza per la seva rigidesa.

Per consegüent, cal suposar que els magistri artium contemporanis de Llull, que havien treballat o encara treballaven pacientment per ampliar les regles de consequentiis, les que establien quines deduccions eren vàlides i quines no ho eren,$^{57}$ difícilment podien acceptar una solució tan simple com la d'una ars inveniendi basada en la combinatòria de l'Ars lul-liana, sorgida al marge de l'exegesi treballosa i exigent dels textos aristotèlics. ${ }^{58}$

Ruiz Simon, que ignora els treballs dels historiadors de la lògica sobre aquest procés, simplifica indegudament les coses quan contraposa una ars inventiva lul-liana, universal i necessària, a una ars inveniendi dels lògics escolàstics incapaç d'arribar a cap resultat concloent perquè restava fixada exclusivament en els Topica d'Aristòtil. En contra del que suposa Ruiz Simon, els escolàstics també cercaven una ars inventiva que fos concloent. ${ }^{59}$

Obsessionat a defensar la pretesa superioritat de la lògica de l'Art sobre la lògica aristotèlica, Ruiz Simon no té prou en compte la riquesa de matisos amb què els lògics medievals debatien els problemes que els preocupaven, que no són pas els problemes que ell els atribueix. Segons els textos que ens han previngut, els medievals no discutien de unitate scientiae ni de arte inventiva sinó: 1) de les expressions constants (De syncategorematatibus); 2) de l'anàlisi i la predicació dels termes i de llur referència, qüestions conegudes com a De proprietatibus terminorum (De suppositionibus, De copulatione, De relativis, De ampliatione, De restrictione, De appelatione); 3 ) de les qüestions especialment difícils (De insolubilibus, De impossibilibus); 4) de les diverses maneres de procedir en la de-

Middle Ages, Munic: Philosophia, 1984, p. 269-270, ho qüestiona. Tanmateix Ruiz Simon hauria d'haver partit del fet que els historiadors de la lògica medieval discuteixen sobre la inventio dels escolàstics.

57 Ruiz Simon no té en compte Jan Pinborg, Logik und Semantik im Mittelalter. Ein Überblick, (Stuttgart - Bad Cannstatt: Frommann-Holzboog, 1972), pp. 77-87, on s'estudia la nova relació entre lògica i ciència causada per la recepció d'Aristòtil, es parla de les consequiències assolibles per procediments no sil·logístics i s'esmenta explícitament Llull (p. 87). Cf. Lorenzo Pozzi, Le consequentiae nella logica medievale (Padova: Liviana,1978), una concisa mise au point que hauria obligat Ruiz Simon a procedir amb més cautela a l'hora de presentar les pressumptes aportacions lògiques de Llull.

${ }^{58}$ Eleonore Stump, Dialectic and Its Place in the Development of Medieval Logic (Ithaca-Londres: Cornell University Press, 1989), pp. 161-162: «The acceptance of topical inferences as necessary»; on s'afirma (p. 161) que podem parlar de «the increased acceptance of the claim that Topical inferences are necessary and not just readily believable (probabile).»

59 Otto Bird, «The formalizing of the Topics in mediaeval logic», Notre Dame Journal of Formal Logic, 1 (1960) 138-149; «The tradition of the logical Topics: Aristotle to Ockham», Journal of the History of Ideas, 23 (1962) 307-323, plantejà la qüestió a partir dels suggeriments de Carl Prantl i Józef M. Bocheński. 
mostració (De obligationibus); 5) de la inferència vàlida (De consequentiis) o invàlida (De sophismatis o De fallaciis); 6) de qüestions de lògica modal (De necessario, De contingenti, De possibili). ${ }^{60}$

Sobre totes aquestes qüestions, tractades pels magistri artium amb una extrema precisió tècnica i un estricte rigor terminològic, Ramon Llull, que emprava un vocabulari del tot peculiar - ple d'idiolectes, menys precís i més imaginatiu-, hi tenia ben poques coses a dir perquè partia de plantejaments d'ordre molt diferent. ${ }^{61}$ La importància estrictament lògica del pensament de Llull sembla relativa o, en tot cas, menor de la que li atribueixen els lul-listes seculars. ${ }^{62}$ Per tot plegat, considero una possibilitat d'allò més remota que s'hagués pogut encetar mai cap ampli debat epistemològic de fundamento scientiarum o de arte inveniendi, entre l'epistemologia de l'Art lul-liana i l'epistemologia aristotèlica dels magistri artium del seu temps, com dóna per fet Ruiz Simon.

D'altra banda, no em sembla pas cap despropòsit pensar que l'Art lul-liana i la lògica escolàstica provenen de paradigmes incommensurables. ${ }^{63}$ Si ho poguéssim dilucidar i si ens fos possible deixar-ho clarament establert, segurament evitaríem més d'un malentès, com el que pateix Ruiz Simon quan s'esforça en va per aconseguir que l'Art de Llull resolgui problemes epistemològics que els lògics escolàstics no tenien.

${ }^{60}$ Philoteus Boehner, Medieval Logic. An Outline of its Development from 1250 to c. 1400 (Chicago: University of Chicago Press, 1952), pp. 6-18; Lorenzo Pozzi, Introduzione alla logica medievale (Brescia: Grafo, 1992); Alexander Broadie, Introduction to Medieval Logic (Oxford: Clarendon, 1993); Handbook of the History of Logic, D. M. Gabbay i J. Woods (ed.) (Amsterdam-Boston: North-Holland, 2008, vol. 2: «Medieval and Renaissance Logic». Cap d'aquests estudis no parla de Llull com d'una figura rellevant en la història de la lògica o de l'epistemologia medievals.

${ }^{61}$ No sembla pas inversemblant la imatge no gens idealitzada del Llull intel-lectual, presentada per Fernand van Steenberghen, recensió de ROL 1, EL 13 (1969) p. 102: «[Les écrits lulliens] reflètent [...] son savoir d'autodidacte, une certaine naïveté ingénue dans la manière d'aborder les problèmes et surtout dans la manière de construire ses 'démonstrations'. Sa connaissance des débats philosophiques de la fin du XIII ${ }^{\mathrm{e}}$ siècle et des écrits qui en sont les principaux témoins (les oeuvres d'Arrevoès, celles de Thomas d'Aquin, de Siger de Brabant, de Bonaventure, de Gilles de Rome etc.) paraît fort limitée. Il vit dans un monde d'idées très personnel et, sur la base d'une information réduite, il échafaude des réfutations dans les cadres de sa propre dialectique, sans établir un véritable dialogue avec ses adversaires.»

${ }^{62}$ En contra del que opina Anthony Bonner, SL 39 (1999), pp. 168-170, considero que caldria no desestimar la crítica de Witold Marciszewski, i Roman Murawski, Mechanization of Reasoning in a Historical Perspective (Amsterdam-Atlanta: Rodopi, 1995), pp.: 45-49 i 62-76, a la «llegenda» (p. 47) del Llull lògic. Segons Marciszewski (p. 74), al capdavall «els procediments d'inferència típics de l' 'ars magna' es basen en intuïcions metafísiques i no pas en regles formals» (the strings of inference typical of 'art magna' are produced by metaphysical insights and not by formal rules). A tot estirar, l'art contindria processos de combinatòria, però no d'inferència lògica.

${ }^{63}$ Thomas S. Kuhn, L'estructura de les revolucions científiques (Santa Coloma de Queralt: Obrador Edèndum, 2007, p. 265): «Quan dues persones que fan servir un mateix vocabulari discuteixen sobre una mateixa situació, si la perceben diferentment, donaran als mots significats diferents. Parlen per dir-ho així, des de punts de vista incommensurables.». Jocelyn N. Hillgarth, $R a$ mon Llull i el naixement del lul-lisme (Barcelona: Curial - Publicacions de l'Abadia de Montserrat, 1998), p. 68: «Llull ne es pot comparar, de manera que resulti convincent amb cap dels grans escolàstics del segle XIII». 


\subsection{L'Art i la fonamentació de les ciències}

Hi ha encara un altra dificultat, també ignorada per Ruiz Simon, per a acceptar la simple possibilitat d'allò que ell s'afigura. És la següent: sembla del tot inversemblant que en un suposat debat de fundamento scientiarum o de arte inveniendi els medis intel-lectuals del tombant del segle XIV haguessin pogut trobar motius suficients per a acceptar una epistemologia deductivament unificadora de totes les ciències, a la manera d'«una ciència totalment deductiva i infal-lible com la geometria euclidiana» que és allò que, segons Ruiz Simon, oferia l'Art lul.liana. ${ }^{64}$

En efecte, a mitjan segle XII, quan els Elementa d'Euclides començaren a ésser llegits en llur integritat, gràcies a la traducció que n'havia fet Gerard de Cremona ${ }^{65}$ sorgí una filosofia religiosa que, basada en un mètode axiomàtic, pretenia unificar totes les ciències. Les Regulae caelestis iuris d'Alà de Lilla sorgiren d'aquesta nova inquietud unificadora del pensament, ${ }^{66}$ si bé l'obra més representativa de la nova tendència fou l'Ars fidei catholicae de Nicolau d'Amiens. Inexplicablement, Ruiz Simon ignora l'existència d'aquesta teologia filosòfica axiomàtica anterior a Llull.

Aquesta filosofia religiosa de tall axiomàtic, com que estava interessada en la demostració, més que no pas en l'exegesi d'autoritats, no restà closa en la seva autosuficiència i, així que començà a difondre's la logica nova, predisposà els seus seguidors a acceptar-la sense ni tan sols haver-s'ho proposat. Ara bé, la nova lògica aristotèlica, tan bon punt fou assimilada, féu evident que la unificació de totes les ciències no era possible. La unificació axiomàtica només havia estat possible perquè hom acceptava que la raó humana podia accedir naturalment a l'ésser diví i, coneixent-lo, podia deduir-ne tota la realitat. Contràriament, la recepció de la teoria de la demostració aristotèlica impedia que l'home s'arrogués aquesta capacitat. Per als nous seguidors d'Aristòtil, no era possible, doncs, deduir la natura de l'ésser diví a partir de l'estructura de les coses creades, això és, partint dels elements de què es componen les coses creades i tenint en compte les causes que les regulen. En consequiència, tampoc no era possible trobar rationes necessariae que demostressin la raonabilitat dels articles de fe. ${ }^{67}$

${ }^{64}$ Ruiz Simon, L'Art de Llull, citat supra, p. 78.

${ }^{65}$ A Source Book in Medieval Science, E. Grant (ed.) (Cambridge-Massachusetts: Harvard University Press, 1974), p. 36.

${ }^{66}$ Alà de Lilla, Regulae caelestis iuris, N. Häring (ed.), AHDLMA 48 (1981), pp. 97-226. Cf. Marie-Dominique Chenu, «Un essai de méthode théologique au XII siècle», Revue des sciences philosophiques et théologiques, 24 (1935) 258-267; «Une théologie axiomatique au XII ${ }^{\mathrm{e}}$ siècle: Alain de Lille», Citeaux en de Nederlanden, 9 (1958) 137-142.

${ }^{67}$ Mechtild Dreyer, Nikolaus von Amiens: Ars fidei catholicae. Ein Beispielwerk axiomatischer Methode (Münster: Aschendorff, 1993), p. 39: «In der Auseinandersetzung mit dem Problem der Reichweite menschlicher Erkenntnis und dem des Umfangs der Erkennbarkeit Gottes und seines Tuns werden sich im Verlauf des 13. Jahrhunderts die beiden wichtigsten Annahmen der Alanischen Konzeption und des von Nikolaus vertretenen Ansatzes als nicht haltbar erweisen. Weder läßt sich Gottes Handeln als ein solches verstehen, das sich im Sinne ewiger und unveränderlicher Gesetze vollzieht [...] noch ist das menschliche Erkennen so beschaffen, daß es aus den geschaffenen Dingen alle Glaubensinhalte zu erkennen oder abzuleiten in der Lage ist.» 
Però, en contrapartida, la pèrdua de la unificació axiomàtica del saber possibilitava que les ciències adquirissin autonomia, i que la teologia, en singularitzar-se, prengués consciència del seu peculiar estatus científic. Tomàs d'Aquino, fent de la teologia una ciència subalterna, i Joan Duns Escot, fent-ne una ciència pràctica, acceptaren, cadascun a la seva manera, la teoria aristotèlica de la ciència. En canvi, Llull, no gens receptiu a la logica nova, restà fidel a una epistemologia de la ciència molt pròxima a l'antic axiomatisme que els escolàstics del segle XIII havien abandonat.

Per consegüent,

1) si la teoria $A$ (la concepció axiomàtica de la ciència) havia estat reemplaçada per

2) la teoria $B$ (l'epistemologia dels Analytica posteriora) que mostrava unes prestacions lògiques superiors en el seu conjunt, resulta del tot inversemblant que

3) la teoria $B$ pogués ésser al seu torn fàcilment reemplaçada per

4) la teoria $A^{\prime}$ (l'Ars lul-liana) si aquesta no era res més que una nova forma de la teoria $A$, sense cap canvi substancial.

En resum, per a un lògic del tombant del segle XIV, els Analytica posterio$r a$ presentaven uns avantatges noètics als quals ell no podia renunciar fàcilment. L'avantatge més important consistia en el fet que la lògica aristotèlica permetia raonar i demostrar sense haver de recórrer a cap metafísica marcada per una religiositat neoplatònica, com ho havia estat la de Nicolau d'Amiens i com ho era la de Ramon Llull. Aquest descobriment d'una dimensió ontològica neutra, prèvia a tot, explica l'aparició i la difusió de la scientia transcendens escotista, una ontologia formal que unirà el pensament medieval amb la filosofia moderna. ${ }^{68}$

\subsection{El pròleg de l'Ars generalis ultima}

Certament, partint de la interpretació aïllada del pròleg de l'Ars generalis ultima, com fa Ruiz Simon, ${ }^{69}$ hom pot suposar que en aquell moment Llull creia que la seva Art, sense fer cap referència a la teologia, podia unificar totes les ciències. Ara bé, segons el meu parer, això no permet pas concloure que des de sempre l'Art hagués estat pensada perquè superés «les anomalies que Llull detectava en la ciència escolàstica del seu temps». Amb tota versemblança, Llull atribuí progressivament a la seva Ars una dimensió epistemològica, però això no vol dir que fos primordialment epistemologia.

${ }^{68}$ Ludger Honnefelder, Scientia transcendens. Die formale Bestimmung der Seienheit und Realität in der Metaphysik des Mittelalters und der Neunzeit (Duns Scotus - Suárez - Wolff - Peirce) (Hamburg: Meiner, 1990).

${ }^{69}$ Ruiz Simon, L'Art de Llull, citat supra, pp. 416-422. 
Crec, doncs, que silenciar que l'Ars generalis ultima en el seu conjunt és una obra tan teològica com ho és qualsevol altra obra lul-liana, i remarcar, en canvi, que en el pròleg de l'obra Llull «justifica la necessitat de la seva Art per raons estrictament epistemològiques», respon a una interpretació esbiaixada, que probablement s'explica per la ideologia secular de l'intèrpret que la proposa. L'Ars generalis ultima constitueix la formulació definitiva del sistema lul-lià, i se'm fa difícil d'acceptar que en el pròleg Llull presenti la seva Art «movent-se en un territori clarament definit per alguns conceptes clau de la teoria de la ciència d'Aristòtil que l'escolàstica havia fet seus».

Voler situar l'Art lul-liana «movent-se» lliurement en l'àmbit aristotèlic, em sembla una decisió difícil de justificar. Certament, en el pròleg de l'Ars generalis utima Llull declara haver elaborat una scientia universalis capaç de fonamentar totes les disciplines. Tanmateix, la finalitat d'aquesta ciència no és substituir l'epistemologia aristotèlica, sinó establir una teologia natural que permeti accedir al Déu veritable, per camins no gens aristotèlics —això és, mitjançant la contemplació dels «noms de Déu», que en l'Art són anomenats principia $\mathrm{o}$ dignitates. ${ }^{70}$

Sense relacionar el pròleg de l'Ars generalis ultima amb altres declaracions de Llull sobre el seu sistema, les afirmacions de Ruiz Simon, correctes en llur literalitat, poden fer creure al lector que en l'Ars generalis ultima Llull, finalment, s'ha desempallegat del llast religiós que enterbolia la seva finalitat originària, estrictament epistemològica: «No s'hi troba, a diferència d'altres obres lul-lianes, cap referència ni a la utilitat de l'Art per a la conversió dels infidels, ni a la presumpta donació d'aquesta per Déu, ni tan sols al problema epistemològic de la necessitat de concordar per mitjà d'uns principis comuns la filosofia i la teologia cristiana [...] Llull parla de la necessitat de l'Art amb relació a la fonamentació de les ciències particulars $i$ ho fa [...] en uns termes que, des de la perspectiva de l'historiador de la filosofia, remeten clarament a Aristòtil.» ${ }^{71}$

Crec que aquesta interpretació del pròleg compendia la ideologia del lul-lisme secular: si Llull té cap validesa, l'hem de trobar en una obra no llastada pel cristianisme. Aquesta obra seria l'Ars generalis ultima, perquè analitzant el seu pròleg és possible demostrar que Llull, al marge dels seus anhels apologètics i dels seus assaigs teològics, la redactà amb una finalitat estrictament epistemològica. Al capdavall l'objectiu de Llull era resoldre el problema de la unificació de les ciències emprant conceptes exclusivament aristotèlics.

És clar que, en principi, una lectura rigorosament secular de l'Ars generalis ultima no és pas impossible —els assaigs ja en demostraran la viabilitat-, però, de moment, els resultats assolits per Ruiz Simon semblen del tot decebe-

${ }^{70}$ Charles Lohr, «Ramon Llull: 'Logica nova'» dins Interpretationen. Hauptwerke der Philosophie. Mittelalter, K. Flasch (ed.) (Sttutgart: Reclam, 1998) p.337 «Hinter der allgemeinen Wissenschaft, die Lull für die speziellen wissenschaftlichen Disziplinen des 13. Jahrhunderts entwarf, steht jedoch die grundlegende Vision einer natürlichen Theologie, die beabsichtigt, sich dem wahren Gott durch eine Methode der Kontemplation der Namen Gottes zu nahern, Lull bezeichnet diese Begriffe als 'dignitates' oder 'principia'.»

${ }^{71}$ Ruiz Simon, L'Art de Llull, citat supra, p. 419. 
dors. Sigui com sigui, allò que no sembla gaire legítim és que Ruiz Simon sense enrogir-se es pugui presentar a si mateix com l'autor d'un «estudi recent sobre Llull [que] apunta quin podria ser el lloc» que correspon a Llull «en el cànon de la història de la filosofia». ${ }^{72}$

\section{L'ART COM A METODOLOGIA DE TEOLOGIA FILOSÒFICA}

Si bé hem d'estar d'acord amb els lul-listes seculars que cal reivindicar la posició que correspon a Ramon Llull en la història del pensament —una posició que no sigui, és clar, la de pare de la literatura catalana, la de fundador del pensament nacional català o la de místic cristià que amalgama el sufisme i la càbala-, crec que aquesta posició no es troba pas on la cerquen els lul-listes seculars. Si Llull hagués estat un lògic, creador d'un sistema d'argumentació rival i superior al sistema lògic d'Aristòtil, per què no el tenen en compte els historiadors de la lògica medieval? Si Llull hagués estat un epistemòleg capaç de crear una teoria de la ciència que substituïa satisfactòriament l'aristotelisme escolàstic, per què no ho veuen així els historiadors de la ciència medieval? ${ }^{73}$

Els lul-listes seculars s'han de decidir per una d'aquestes dues proposicions alternatives:

1) els historiadors de la lògica medieval s'equivoquen - tal com s'equivocaren els contemporanis de Llull— quan no concedeixen a Llull la importància lògica i epistemològica que els lul-listes seculars creuen haver demostrat que es mereix;

2) els lul-listes seculars s'equivoquen quan donen a la lògica i a l'epistemologia de Llull una importància que els seus contemporanis no reconegueren i que els medievalistes es resisteixen a admetre.

Amb tots els matisos que calgui fer, la meva opinió actual — fa un parell d'anys no pensava pas el mateix - és que cal decantar-se per la segona proposició alternativa: els lul-listes seculars s'equivoquen. Llull no fou cap lògic «professional», és a dir, algú que, havent seguit de jove els cursos ordinaris de lògica, s'hauria emparat de les tècniques habituals entre els lògics i les dominava. Llull mai no comentà els tractats aristotèlics amb el rigor amb què ho feien els magistri artium, i molt probablement tenia un coneixement superficial dels tractats aristotèlics inclosos en la logica nova. Llull no partia dels plantejaments dels magistri artium, actius a les universitats, ni feia servir amb rigor llur terminologia. Llull, malgrat els títols d'algunes de les seves obres, no ens ha dei-

72 Josep M. Ruiz Simon, «Seixanta anys després. Els estudis sobre Ramon Llull», dins Tomàs i Joaquim Carreras Artau, Historia de la filosofía española. Filosofía cristiana de los siglos XIII al XV (reedició, Barcelona-Girona: IEC - Diputació de Girona), vol. 1, p. 26, nota 39.

${ }^{73}$ Ruiz Simon no esmenta cap article de Knowledge and the Sciences in Medieval Philosophy, J. E. Murdoch, S. Knuttila, S. Ebessen i altres (ed.) (Helsinki: Yliopistopaino, 1990), 3 vols. (Proceedings of the Eighth International Congress of Medieval Philosophy). 
xat cap tractat lògic en sentit estricte. Només en el sentit en què diem que els atomistes grecs foren precursors de la física atòmica, podem dir que Llull ha estat un lògic precursor de la moderna informàtica. ${ }^{74}$ Des del punt de vista matemàtic, la contribució del lul-lisme a la combinatòria és negligible. ${ }^{75} \mathrm{~A}$ diferència dels primers escolàstics d'Oxford ${ }^{76} \mathrm{i}$ dels filòsofs àrabs de l'època clàssica, Llull treballà aïlladament com un autodidacte, sense haver rebut cap formació rigorosa ni en lògica ni en matemàtica. ${ }^{77}$

Segurament, el lloc que correspon a Llull en la història del pensament no es troba en la lògica o l'epistemologia, sinó en la teologia filosòfica, això és, en l'esforç racional per donar compte (apología) de la fe de què viu el creient. ${ }^{78}$ Aquesta activitat intel-lectual, a mig camí entre el sagrat i el profà, la religiositat i la mundanitat, la fe i la raó, la teologia i la filosofia, gaudeix des de fa uns quants anys d'un cert reviscolament. Diversos factors hi han contribuït. En primer lloc, la crítica a què els mateixos filòsofs analítics sotmeteren llurs asseveracions sobre la manca de sentit del llenguatge religiós. ${ }^{79}$ En segon lloc, el prestigi aconseguit els darrers anys per filòsofs que mai no havien desdenyat el fet religiós, com és ara Paul Ricoeur, Emmanuel Levinas o Hilary Putnam. En tercer lloc, la constatació que no sols el significat de temes religiosos generals, com és ara el llenguatge mític, el sentit de la vida o l'activitat simbòlica, pot ésser

${ }^{74}$ Llegeixo amb molta prevenció l'article d'Eusebi Colomer, «De Ramon Llull a la moderna informàtica», dins El pensament als Països Catalans durant l' edat mitjana i el Renaixement (Barcelona: IEC - PAM, 1997). Llull pot haver tingut intuïcions «tècniques» que podem considerar suggeridores, però difícilment podem afirmar que hagi fet cap aportació important en el camp de les ciències de la computació; cf. Marie Ange Gesquière, «Raymond Lulle et la tecnique», dins Les philosophes et la technique, P. Chabot i G. Hottois (ed.) (París: Vrin, 2003), pp. 49-69.

75 Eberhard Knobloch, «Combinatorial Probability», dins Companion Encyclopedia of the History and Philosophy of the Mathematical Sciences, I. Grattan-Guiness (ed.) (Londres - Nova York: Routledge, 1994), vol. 2, p. 1287: «Ramon Lull taught [...] that knowledge can be increased by exploring pairwise combinations of certain categories. While he himself contributed little to the theory of combinatorics, the adherents of 'Lullism' [...] published numerous and voluminous books on the subject. These studies had little or no influence on the mainstream of mathematics.»

${ }^{76}$ Alistair C. Crombie, Robert Grosseteste and the Origins of Experimental Science, 11001700 (Oxford: Clarendon, 1953), pp. 91-127: «Mathematical Physics».Cecilia Trifogli, Oxford Physics in the Thirteenth Century (ca. 1200-1270). Motion, Infinity, Place and Time (Leiden-Boston: Brill, 2000).

77 Roshdi Rashed, «Combinatoire et métaphysique. Ibn Sinna, Al Tusi et Al-Halabi», dins Les doctrines de la science de l'Antiquité à l'Âge classique (Lovaina: Peeters, 1999), p. 62: «Raymond Lulle [...] combine des notions selon des règles mécaniques, dont les résultats se sont avérés plus tard des arrangements ou des combinaisons. Mais Lulle n'a rien emprunté aux mathématiques, et n'a jamais reconnu dans sa propre démarche quoi que ce soit de mathématique.» En aquest sentit, cal dir que el treball d'Anthony Bonner, The Art and Logic of Ramon Llull. A User's Guide (Leiden-Boston, Brill, 2007), ha provat que en l'Art lul-liana hi ha procediments discursius mecànics que podem considerar una mena de combinacions; però de cap manera hem de donar per fet que hagi demostrat que l'Art lul-liana és un sistema lògic ben estructurat amb una base matemàtica sòlida.

$781 \mathrm{Pe} 3,15$.

79 New Essays in Philosophical Theology, A. Flew i A. MacIntyre (ed.) (Nova York: Macmillan, 1955). 
analitzat filosòficament, ans també ho pot ésser el contingut del credo cristià. En aquest sentit, hi ha filòsofs actuals de la religió que accepten que la Trinitat, l'encarnació o la justificació són susceptibles de contenir quelcom de significatiu. ${ }^{80}$ En aquest punt, caldria veure críticament què pot aportar a l'acuïtat analítica actual la ingenuïtat raonadora de Llull quan amb la seva Ars pretén mostrar la raonabilitat inherent als misteris del cristianisme.

Llull fou un laic culte que, arran de la seva conversió, inicià una activitat apologètica que li exigí una seriosa preparació intel·lectual. Com que no pogué seguir els cursos regulars d'arts i de teologia, es formà a si mateix amb múltiples lectures. En resultà un sistema original de teologia filosòfica que anà desenvolupant i simplificant alhora: reduint el nombre de dignitats, precisant les diverses menes de combinatòria, establint els diferents principis correlatius o recorrent a determinats punts transcendents. L'objectiu originari d'aquest sistema de teologia filosòfica no era, com pretén Ruiz Simon, «corregir el caràcter deficient de la lògica aristotèlica», ans donar un sentit religiós a tota la realitat. Amb aquesta finalitat Llull inventà una lògica que no tendia a la formalitat, com feia la lògica escolàstica, ans era explícitament material o intensional. El seu objectiu no era formalitzar els processos d'argumentació o resoldre problemes d'epistemologia de la ciència, sinó unir la lògica i la metafísica, a fi d'assolir una «lògica teològica» (Theologik) que donés compte del contingut de la fe cristiana. ${ }^{81}$ Com sagaçment ha assenyalat Mark D. Johnston, el pensament de Llull és sostingut per una «lògica espiritual», i el seu discurs és configurat per una «retòrica evangèlica». ${ }^{82}$ Wilhelm Risse, un gran historiador de la lògica, ho digué de manera sentenciosa: «L'Ars magna de Llull s'orienta místicament vers allò que és supraracional, i no pas lògicament vers allò que és racional». ${ }^{83}$

Probablement un lul-lista secular radical, admirador ressagat de Rudolf Carnap, voldria poder interpretar l'Art lul-liana com un logischer Aufbau der Welt, però sortosament les coses són com són i no com nosaltres voldríem que fossin. Els historiadors ens diuen que tot sembla indicar que l'Art lul-liana no ha d'ésser considerada una doctrina precursora del neopositivisme lògic, ans ha d'ésser inserida en la tradició d'una teologia natural sapiencial que interpretava místicament la natura com si fos un llibre que manifestava el mateix Déu revelat en la Bíblia. En aquest sentit, l'intellectus fidei, la comprensió racional de la fe, tal com l'entenia Llull, esdevenia una ars inveniendi, un mètode per a descobrir -

${ }^{80}$ The Oxford Handbook of Philosophical Theology, Th. P. Flint i M. Rea (ed.) (Oxford: Oxford University Press, 2009), pp. 6-7.

81 Jan Rohls, Philosophie und Theologie in Geschichte und Gegenwart (Tübingen: Mohr-Siebeck, 2002), p. 237: «Lullus entwarf eine Logik, die nicht länger eine nur formale, sondern eine materiale Logik ist. Und das bedeutet, daß er eine Vereinigung von Logik und Metaphysik in Sinne einer philosophischen Theologik konzipierte.»

82 Mark D. Johnston, The Spiritual Logic of Ramon Llull (Oxford: Clarendon, 1987); The Evangelical Rhetoric of Ramon Llull. Lay Learning and Piety in the Christian West around 1300 (Nova York - Oxford: Oxford University Press, 1996).

${ }^{83}$ Wilhelm Risse, Die Logik der Neunzeit (Stuttgart - Bad Cannstatt: Frommann-Holzboog, 1964), vol. 1, p. 533: «Lulls 'Ars magna' ist mystisch auf das Übervernünftige», nicht logisch auf das Vernünftige ausgerichtet.» 
de manera vàlida tant per als fidels cristians, com per als infidels musulmans i jueus- els trets essencials de la divinitat, uns trets que, segons pretenia demostrar l'Art, es corresponien amb els dogmes fonamentals del cristianisme. ${ }^{84}$ Llull s'avançava al Liber creaturarum de Ramon Sibiuda, amb raó anomenat també Theologia naturalis. ${ }^{85}$ D'aquesta manera, en el sistema de Llull els conceptes, lluny d'esdevenir variables lògiques, prenien una significació teològica i l'Art esdevenia una «teologia del concepte» (Begriffstheologie). ${ }^{86}$

Voler fer de Llull un epistemòleg equiparable als millors lògics medievals és desenfocar les coses. Vittorio Hösle elogià Llull perquè ha estat un dels pensadors que més ha posat en relleu «l'esperit especulatiu del cristianisme» (der spekulative Geist des Christentums) ${ }^{87} \mathrm{Si}$ fos així, semblaria més prometedora la recerca per precisar en què consisteix el vigor especulatiu de Llull aplicat a la comprensió filosòfica del cristianisme, que no pas l'intent de descobrir una pretesa perspicàcia lògica per a resoldre qüestions epistemològiques, per a les quals Llull, llevat que es demostri el contrari, no tenia cap preparació especial. Tot sembla indicar que la grandesa de la lògica de Llull es troba en la vigoria de la seva especulació, capaç de crear un sistema de teologia filosòfica, limitat per les seves preocupacions i pels plantejaments medievals, però internament consistent.

Molts anys abans i des d'una altra perspectiva, Alfred N. Whitehead, ja havia parlat del tirat racionalitzador del cristianisme. Whitehead, assenyalà que, a diferència del budisme, que és una metafísica convertida en religió, el cristianisme és una religió - això és, una manera de viure moralment sota la guia d'unes creences supraracionals - que cerca una metafísica que originàriament no posseeix —això és, busca una dogmàtica, que mai no assoleix del tot. Per a Whitehead, un element constant en la història de l'Església es troba en el fet d'intentar obstinadament racionalitzar la religió cristiana, és a dir, de construir una teologia filosòfica sobre allò que mai no és del tot exclusivament racional: la fe

${ }^{84}$ Walter Sparn, «Natürliche Theologie», dins Theologische Realenzyklopädie (Berlín Nova York: de Gruyter, 1994), vol. 24, pp. 86-87: «Die sapientiale Auffassung von natürlicher Theologie wurde in der Mystik und vor allem im platonisch inspirierten Renaissance Humanismus weiterentwickelt. Sie hatte zunächst theologische Absichten, konnte sich aber, da sie das Buch der Natur dem der Schrift gleichstellte, der Offenbarungstheologie auch entziehen. Verbürgt der intellectus fidei die Einheit von Wahrheit und die Lesbarkeit des Buches der Natur, dann können die allgemein, d.h. von Christen, Juden und Moslems anerkannten Wesenseigenschaften Gottes als Grundlage für eine kategoriale ars inveniendi so formalisiert werden, daß sogar einem Nichtchristen der trinitarische Gottesbegriff als logische Bedingung vernünftiger Welterkenntnis einleuchten sollte: Dieses Programm Raymundus Lullus hat dann die erste monographische natürliche Theologie realisiert, die lange einflußreiche Theologia naturalis seu Liber creaturarum des Raimund von Sabunde.»

${ }^{85}$ Ramon Sibiuda, El llibre de les criatures, J. de Puig (trad.) (Barcelona: Edicions 62, 1992); Jaume de Puig, La filosofia de Ramon Sibiuda (Barcelona: IEC, 1997).

${ }^{86}$ Wilhelm Schmidt-Biggemann, Philosophia perennis. Historische Umrisse abenländlischer Spiritualität in Antike, Mittelalter und Früher Neunzeit (Frankfurt del M.: Suhrkamp, 1995), pp. 129-143.

87 Vittorio Hösle, «Einführung» a Raimundus Lullus, Die Neue Logik, Ch. Lohr, V. Hösle i W. Büchel (ed.) (Hamburg: Meiner, 1985), p. LXXXII. 
del creient. ${ }^{88}$ Des d'aquest punt de vista, Llull seria un pensador genuïnament cristià.

Tendeixo a pensar que la recerca lul·liana hauria de començar per establir una llista dels pensadors que, d'una manera o altra, s'hagin interessat pel grau de raonabilitat que pugui tenir el cristianisme: Justí el Filòsof, Climent d'Alexandria, Dionisi Areopagita, Joan Escot Eriugena, Pere Abelard, Mestre Eckhart, Nicolau de Cusa, John Locke, Nicolas Malebranche, Gottfried Leibniz, Immanuel Kant, Georg W. Hegel, Friedrich Schleiermacher, Albrecht Ritschl, Maurice Blondel, Michel Henry, Henry Duméry... Seria, en aquesta tradició de filòsofs interessats per entendre el cristianisme, i no pas en la història de la lògica estricta, on caldria cercar críticament quin és el lloc que innegablement correspon a Llull en la història del pensament. Què ha dit Llull, gràcies a la seva Art, que no hagi dit ningú més? Però també, què ha afirmat Llull que avui hàgim de considerar insostenible? En definitiva, què ha suggerit Llull que pugui orientar la reflexió actual sobre què és el cristianisme?

${ }^{88}$ Alfred North Whiehead, Religion in the Making (Nova York: Macmillan, 1926), p. 50: «Buddhism is the most colossal example in history of applied metaphysics. Christianity took the opposite road. It has always been a religion seeking a metaphysic, in contrast to Buddhism which is a metaphysic generating a religion.» 